\title{
Essential need for rethink of COPD airway pathology: implications for new drug approaches for prevention of lung cancer as well as small airway fibrosis
}

\section{Sukhwinder Singh Sohal \\ Eugene Haydn Walters}

School of Health Sciences, University of Tasmania, Launceston, TAS, Australia
Correspondence: Sukhwinder Singh Sohal School of Health Sciences, University of Tasmania, Locked Bag - 1322, Newnham Drive, Launceston, TAS 7248, Australia

Tel +6I 363245434

Email sssohal@utas.edu.au
This article was published in the following Dove Press journal:

International Journal of COPD

7 September 2017

Number of times this article has been viewed

\section{Dear editor}

We read with interest the recent comprehensive review by Sowmya P Lakshmi et al on potential new therapies for COPD in the International Journal of Chronic Obstructive Pulmonary Disease. ${ }^{1}$ The review says that only by understanding the core pathological processes, new therapeutics emerge, and it encourages that leading respiratory journals are recognizing this. However, we would suggest that, in this review, the overall view of the pathology of COPD airway disease does not reflect the current literature. In particular, the airway wall in at least mild to moderate COPD is hypo-cellular and hypo-vascular, with markedly active epithelial-mesenchymal transition (EMT) ${ }^{2}$ as part of epithelial activation and reprogramming. ${ }^{3}$ This process is closely related to small airway fibrosis and airflow obstruction. Inhaled corticosteroids (ICSs) affect these key epithelial cellular activation and vascular aspects of $\mathrm{COPD},{ }^{2}$ and more research on alternatives to corticosteroid on these aspects is urgently needed. It is of interest that the peroxisome proliferator-activated receptor system that the reviewers mention has implication for EMT induction, ${ }^{1}$ as has the TGF/Activin family and the Wnt system; these pathways are replete with potential drug targets.

There is certainly marked innate cellular activation within the airway lumen in COPD, due to oxidant attack or chronic infection or indeed both. We have shown that the airways in COPD are especially vulnerable to rhinovirus infection and bacterial infection by non-typeable Haemophilus influenzae and Pneumococci, because of marked upregulation of their respective major epithelial cell-surface adhesion sites, intercellular adhesion molecule-1, and platelet-activating factor receptor. ${ }^{4}$ Blocking these receptors could potentially have great positive effect on airway luminal inflammation, acute exacerbations, and the downhill natural history of COPD. ${ }^{4}$

Lung cancer is strongly related to COPD and not only smoking. In epidemiological studies, there is a strong suggestion that patients on ICSs at high doses are associated with an appreciable (50\%) reduction in the cancer risk. Epithelia with active EMT are highly vulnerable to malignant transition, and EMT in COPD airways may well be the link between airway fibrosis and cancer development that is inhibited by ICS. Recently, we showed strong correlations between EMT activity in the leading edge of invasive cancer and EMT activity even in the non-malignant airways from which the tumor originated. ${ }^{5}$ Such a link would have huge implications for therapeutic and 
public health policy, since drugs acting on epithelial activation, and the EMT system would need to be given early in the natural history of COPD, not just to suppress airway luminal inflammation, but also to suppress epithelial activation, EMT, and related fibrotic and malignant consequences.

In summary, better insights into core airway pathologies in COPD are vital, and of those EMT may well represent a fundamentally important aspect for airway wall fibrosis and cancer development. Finally, we may get an integrated understanding of this airway disease translatable into a new paradigm for attacking fundamental disease mechanisms early, rather than only symptoms and luminal "inflammation" in later-stage patients.

\section{Acknowledgments}

The authors body of work on EMT in COPD has been supported by the Clifford Craig Foundation.

\section{Disclosure}

The authors report no conflicts of interest in this communication.

\section{References}

1. Lakshmi SP, Reddy AT, Reddy RC. Emerging pharmaceutical therapies for COPD. Int J Chron Obstruct Pulmon Dis. 2017;12:2141-2156.

2. Sohal SS, Soltani A, Reid D, et al. A randomized controlled trial of inhaled corticosteroids (ICS) on markers of epithelial-mesenchymal transition (EMT) in large airway samples in COPD: an exploratory proof of concept study. Int J Chron Obstruct Pulmon Dis. 2014;9:533-542.

3. Shaykhiev R, Crystal RG. Early events in the pathogenesis of chronic obstructive pulmonary disease. Smoking-induced reprogramming of airway epithelial basal progenitor cells. Ann Am Thorac Soc. 2014;11(Suppl 5): S252-S258.

4. Shukla SD, Sohal SS, O'Toole RF, Eapen MS, Walters EH. Platelet activating factor receptor: gateway for bacterial chronic airway infection in chronic obstructive pulmonary disease and potential therapeutic target. Expert Rev Respir Med. 2015;9(4):473-485.

5. Mahmood MQ, Ward C, Muller HK, Sohal SS, Walters EH. Epithelial mesenchymal transition (EMT) and non-small cell lung cancer (NSCLC): a mutual association with airway disease. Med Oncol. 2017;34(3):45. 


\section{Authors' reply}

Sowmya P Lakshmi ${ }^{1,2}$

Aravind T Reddy ${ }^{1,2}$

Raju C Reddy ${ }^{1,2}$

'Department of Medicine, Division of Pulmonary, Allergy and Critical Care Medicine, University of Pittsburgh School of Medicine, ${ }^{2}$ Veterans Affairs Pittsburgh Healthcare System, Pittsburgh, PA, USA

Correspondence: Raju C Reddy

Department of Medicine, Division of Pulmonary, Allergy and Critical

Care Medicine, University of Pittsburgh School of Medicine

3459 Fifth Avenue, Pittsburgh, PA I52 13, USA

$\mathrm{Tel}+\mathrm{I} 4 \mid 23606823$

Fax +I 4123601919

Email reddyrc@upmc.edu

\section{Dear editor}

We thank Drs Sohal and Walters for their interest in our review entitled "Emerging pharmaceutical therapies for COPD". ${ }^{1}$ In their Letter to the Editor, they called attention to the role of epithelial-mesenchymal transition (EMT) in COPD. Although our article covered the most recent literature regarding various aspects of COPD pathophysiology, it was by no means intended to be a comprehensive overview but instead focused on current and impending therapeutic advances. Consequently, our coverage of this and certain other areas was quite limited. Nevertheless, we agree with Drs Sohal and Walters regarding the significance of EMT in COPD pathology and its potential therapeutic implications, especially in cases associated with tobacco smoking. ${ }^{2,3}$ Airways of COPD patients are known to exhibit EMT-associated characteristics $^{1,4}$ and transcriptome analyses have demonstrated upregulation of signaling pathways, including the TGF- $\beta$ pathway, that are known to induce EMT. ${ }^{3}$ Association between inhaled corticosteroid treatment and suppression of EMT has also been observed. ${ }^{5}$ Further supporting involvement of EMT in COPD pathogenesis, our article noted the promising benefits of PPAR $\gamma$ agonists that have been shown to influence EMT processes. ${ }^{6}$ Thus, we are in full accord with
Drs Sohal and Walters in recognizing the potential of EMT as a target for COPD treatment.

We would like to note, however, that EMT is also a normal, physiological process that is critical in wound healing. Accordingly, the EMT-like features observed in COPD airway epithelium may represent an essential tissue repair mechanism activated in response to chronic airway inflammation/injury associated with COPD. Accordingly, future investigations evaluating potential COPD therapies targeting this process must address the possibility that such strategies may compromise the ability of the airway epithelium to recover and potentially regain some or all of its normal function.

We hope that, although a detailed discussion of EMT was beyond the scope of our review, we successfully highlighted the potential of the most promising therapeutics for COPD. We thank Drs Sohal and Walters for their thoughts and insights into this stimulating area of study and appreciate their input.

\section{Disclosure}

The authors report no conflicts of interest in this communication.

\section{References}

1. Lakshmi SP, Reddy AT, Reddy RC. Emerging pharmaceutical therapies for COPD. Int J Chron Obstruct Pulmon Dis. 2017;12:2141-2156.

2. Milara J, Peiro T, Serrano A, Cortijo J. Epithelial to mesenchymal transition is increased in patients with COPD and induced by cigarette smoke. Thorax. 2013;68:410-420.

3. Shaykhiev R, Crystal RG. Early events in the pathogenesis of chronic obstructive pulmonary disease. Smoking-induced reprogramming of airway epithelial basal progenitor cells. Ann Am Thorac Soc. 2014; 11 Suppl 5:S252-S258.

4. Nishioka M, Venkatesan N, Dessalle K, et al. Fibroblast-epithelial cell interactions drive epithelial-mesenchymal transition differently in cells from normal and COPD patients. Respir Res. 2015;16:72.

5. Sohal SS, Soltani A, Reid D, et al. A randomized controlled trial of inhaled corticosteroids (ICS) on markers of epithelial-mesenchymal transition (EMT) in large airway samples in COPD: an exploratory proof of concept study. Int J Chron Obstruct Pulmon Dis. 2014;9:533-542.

6. Reddy AT, Lakshmi SP, Reddy RC. PPARgamma as a novel therapeutic target in lung cancer. PPAR Res. 2016;2016:8972570.

Dove Medical Press encourages responsible, free and frank academic debate. The content of the International Journal of Chronic Obstructive Pulmonary Disease 'letters to the editor' section does not necessarily represent the views of Dove Medical Press, its officers, agents, employees, related entities or the International Journal of Chronic Obstructive Pulmonary Disease editors. While all reasonable steps have been taken to confirm the content of each letter, Dove Medical Press accepts no liability in respect of the content of any letter, nor is it responsible for the content and accuracy of any letter to the editor.

International Journal of COPD

\section{Publish your work in this journal}

The International Journal of COPD is an international, peer-reviewed journal of therapeutics and pharmacology focusing on concise rapid reporting of clinical studies and reviews in COPD. Special focus is given to the pathophysiological processes underlying the disease, intervention programs, patient focused education, and self management protocols.

\section{Dovepress}

This journal is indexed on PubMed Central, MedLine and CAS. The manuscript management system is completely online and includes a very quick and fair peer-review system, which is all easy to use. Visit $\mathrm{http}: / / \mathrm{www}$.dovepress.com/testimonials.php to read real quotes from published authors. 